\title{
Kinetic study on peroxidase inactivation and anthocyanin degradation of black cherry tomatoes (Solanum lycopersicum cv. OG) during blanching
}

\author{
HO THI NGAN HA ${ }^{1,2^{*}}$, NGUYEN MINH THUY ${ }^{3 \odot}$
}

\author{
${ }^{1}$ Faculty of Agriculture and Natural Resources \\ An Giang University, \\ Vietnam \\ ${ }^{2}$ Vietnam National University \\ Ho Chi Minh City, Vietnam \\ ${ }^{3}$ Department of Food Technology, College of Agriculture \\ Can Tho University, Vietnam \\ *corresponding author: phone: 084 919965143; e-mail: htnha@agu.edu.vn
}

\section{Summary}

Introduction: Blanching is a necessary treatment stage in processing of tomato products to inactivate enzymes. However, it may cause the degradation of nutrients.

Objective: In this study, the kinetics of thermal peroxidase inactivation and anthocyanin degradation in black cherry tomatoes (cv. OG) were determined to predict the quality changes during the blanching.

Methods: Tomatoes were blanched at five levels of temperature $\left(75-95^{\circ} \mathrm{C}\right)$ for five time periods $(30-150 \mathrm{~s})$.

Results: It was found that as the blanching temperature increased and the blanching time is prolonged, more peroxidase was inactivated and the greater number of anthocyanins was lost. The thermal peroxidase inactivation and anthocyanin degradation showed an apparent first-order reaction with the activation energy of $129.96 \mathrm{~kJ} / \mathrm{mol}$ and $65.99 \mathrm{~kJ} / \mathrm{mol}$, respectively. Peroxidase and anthocyanin in black cherry tomatoes were found to be heat-sensitive.

Conclusion: These kinetic parameters were necessary to select and design appropriate blanching conditions for black cherry tomatoes on larger scale processing.

Key words: anthocyanin, black cherry tomatoes, blanching, kinetic study, peroxidase, Solanum lycopersicum cv. $O G$

Słowa kluczowe: antocyjany, czarne pomidorki koktajlowe, blanszowanie, badania kinetyczne, peroksydaza, Solanum lycopersicum cv. OG 


\section{INTRODUCTION}

Black cherry tomatoes (Solanum lycopersicum L.) [1] are tomatoes with a purplish-brown color of skin [2]. They have been just grown in Vietnam in recent years and received great attention from consumers. In addition to the common bioactive compounds such as lycopene and vitamin C, black cherry tomatoes can also produce anthocyanin, predominantly in the skin and outer tissue that other tomato cultivars do not have [3].

Anthocyanin is a major group of flavonoids found in black tomatoes. The total anthocyanin content in the extract of purple tomatoes V118 (a non-GMO tomato variety) was $72.31 \mathrm{mg} / 100 \mathrm{~g}$ dried weight (DW), which included $50.18 \mathrm{mg} / 100 \mathrm{~g}$ DW of petunidin-3-O-( $p$-coumaryl)-rutinoside-5-O-glucoside, $13.09 \mathrm{mg} / 100 \mathrm{~g}$ DW of malvidin-3-O-( $p$-coumaryl)rutinoside-5-O-glucoside, and $9.04 \mathrm{mg} / 100 \mathrm{~g} \mathrm{DW}$ of petunidin-3-O-caffeoyl-rutinoside-5-O-glucoside [3]. A series of in vitro and in vivo studies have demonstrated that anthocyanin has health-promoting effects and plays an important role in reducing degenerative and chronic diseases [4]. Black cherry tomatoes with a high concentration of these phytochemicals may have greater antioxidant potential and therefore help to lower the risk of heart diseases and cancer better [3].

Due to their health benefits, black cherry tomatoes are commonly used as a fresh vegetable or processed into liquid products such as ketchup, puree, and sauce [1]. Tomato blanching is an essential step in the processing of these products to destroy enzymes which directly responsible for undesirable sensory and nutritional changes afterward [5]. Peroxidase (POD) is well-known as one of the most heat stable enzymes present in fruits and vegetables, therefore, it is often chosen as an indicator enzyme for blanching [6] because if POD is inactivated, other enzymes that cause quality problems will also be destroyed [7]. However, like other thermal treatment operations, blanching can cause a considerable loss of heat-sensitive bioactive compounds [8]. Particularly, in black cherry tomatoes, anthocyanin is synthesized in response to light, it is concentrated mainly in the outer peel, which makes the fruits look attractive but more easily exposed to harmful environmental factors during processing [9]. Moreover, this pigment is sensitive to high temperature [10], therefore, it may be suffered a lot of loss during the blanching which affected the color and biological value of fruits.

Kinetic modeling is a helpful method in quantitative analysis in which mathematical models include formulations that show the relationship between an acquisition indicator (for example peroxidase activity, anthocyanin content) and investigated factors (such as temperature, time) [11]. It is a concise way to express physicochemical behavior in mathematical terms [11]. Knowledge of kinetic modeling consists of reaction order, the reaction rate constant and activation energy are necessary for predicting food quality changes and optimizing the processes, especially heat treatment $[10,12]$.

Thermal inactivation kinetic studies in POD enzyme for different sources such as carrot [13], green asparagus [14], guava [15], zucchini [16], garlic [17], sweet corn and waxy corn [18], mangosteen [19], pumpkin [20] were observed in the wide range of 70 to $100^{\circ} \mathrm{C}$. POD present in the tissues of fruits and vegetables as a combination of different isoenzymes with various thermal conditions [18]. Also, POD exists in plants both in soluble form - in the cell cytoplasm and insoluble form - when forming covalent and ionic bonds with the cell wall [21]. Thus, differences in the heat tolerance of POD vary significantly among fruit and vegetable cultivars, species, environmental conditions, and other factors [21].

Similarly, various kinetic parameters for anthocyanin degradation under heating were reported for the strawberry [22], raspberry [23], black rice [24], purple sweet potato [25], black carrot [26], mangosteen [12] and blackberry [27]. The degradation rate constant and activation energy during thermal treatment are dependent upon the stability of the anthocyanin which depends on structure, composition, physicochemical characteristics and presence of organic acids or other flavone in fruits [3].

The differences between kinetic parameters from several sources indicate the importance and necessity of kinetic analysis for individual fruits and vegetables because inappropriate values or small errors in the calculation of these parameters can greatly affect the prediction [21]. Currently, there is no published work concerning the thermal inactivation of POD and degradation of anthocyanin in whole tomato fruit, especially black cherry tomato. Therefore, the objective of the present study was a quantification of the effect of conventional blanching on POD inactivation and anthocyanin degradation of a new variety of black cherry tomato (Solanum lycopersicum cv. OG) cultivated in Vietnam in the whole fruit. Moreover, another novelty of this study was that black cherry tomatoes were vacuum-infiltrated before blanching to replace the gaseous components inside the fruits with water. This treatment helps the heat transfer process during blanching faster to avoid the loss of bioactive compounds, especially anthocyanins, which are mainly concentrated in 
the outer skin. This may affect the kinetics of peroxidase inactivation and anthocyanin degradation upon blanching. The reaction kinetic approach was applied to be able to predict the quantity changes during blanching at different temperatures and exposure times and thereby selecting proper thermal processing conditions.

\section{MATERIALS AND METHODS}

\section{Black cherry tomatoes}

American black cherry tomato (cv. OG) seeds were provided from F1508 seed shop (Ho Chi Minh City, Vietnam) and grown in the greenhouse of Nam Long Business and Production Facility in Vinh Long province, Vietnam. Fruits were harvested at full ripening (32 days after fruit formation) with the fruit diameter of $25.11 \pm 1.83 \mathrm{~mm}$, the total soluble solid content and $\mathrm{pH}$ value of $6.17 \pm 0.12$ Brix and $4.43 \pm 0.06$, respectively, the whole fruit firmness of $899 \pm 45 \mathrm{~g} / \mathrm{cm}^{2}$. Tomatoes were packed into polyvinyl chloride plastic boxes and then put into cardboard containers. Both packages were perforated for ventilation. They were transported to the Food Technology Laboratory in Can Tho University, Vietnam within 1 to $2 \mathrm{~h}$. Fruits were washed with tap water and then immersed in ozone-aerated water for $15 \mathrm{~min}$ using an ozone generator (Z755, 2-nozzle, Vietnam, ozone-generation capacity of $80.4 \mathrm{mg} / \mathrm{h}$ ) to kill microorganisms on the surface. The tomato weight was $1500 \mathrm{~g}$, the material and water ratio was 1:2. Then, the tomatoes were vacuum-treated in water using a vacuum generator (Rocker 400, Laftech, Australia) to replace gases inside the fruit pores with the liquid, thereby the thermal conductivity of fruits was increased during subsequent blanching. The vacuum level of $620 \mathrm{mmHg}$ and the infiltration period of $22 \mathrm{~min}$ were selected, the ratio of tomatoes and distilled water was 1:1. After vacuum treatment, the mixture of tomatoes and water was brought to the atmospheric pressure and allowed to stand for an additional $15 \mathrm{~min}$ [28]. Then, fruits were removed from the water and drained until used as a raw materials for the blanching process. The initial anthocyanin content was $4.41 \mathrm{mgCE} / 100 \mathrm{~g}$.

\section{Tomatoes blanching process}

Fruits were blanched at five temperature levels (75, $\left.80,85,90,95^{\circ} \mathrm{C}\right)$. At each temperature, fruits were blanched for five time periods $(30,60,90,120$,
$150 \mathrm{~s}$ ). The blanching process was done by placing $1 \mathrm{~kg}$ of tomatoes in a rectangular stainless steel basket $(25.5 \mathrm{~cm}$ long, $10 \mathrm{~cm}$ wide, $6.5 \mathrm{~cm}$ high, $0.5 \mathrm{~cm}$ square hole size) and then immersed in a thermostatic bath (Rex C-90, Memmert, Germany), in which the ratio of fruits and water was 1:2. After blanching, tomatoes were rapidly cooled by soaking in ice water $\left(10^{\circ} \mathrm{C}\right)$ for $1 \mathrm{~min}$ to prevent further thermal decomposition. The experiment was performed in three replications.

\section{Analytical methods}

\section{Peroxidase activity}

The activity of peroxidase (POD) of tomatoes was defined according to the colorimetric method using guaiacol and hydrogen peroxide as the reaction substrate of Gonçalves et al. [13] and Morales-Blancas et al. [21] with some modifications. Tomato puree $(20 \mathrm{~g})$ was put in a $250 \mathrm{ml}$ conical flask along with $100 \mathrm{ml}$ of $1 \mathrm{M} \mathrm{NaCl}$ solution. The extraction was performed for $10 \mathrm{~min}$ with an assistance of a shaker (SK600, Lab Companion, Korea) at a speed of $180 \mathrm{rpm}$ and centrifugation (Z323K, Hermle Labourtechnik $\mathrm{GmbH}$, Germany) was carried out afterwards at $7000 \times \mathrm{g}$ for $10 \mathrm{~min}$ to separate the mixture. The substrate solution of POD included $0.1 \mathrm{ml}$ of $99.5 \%$ guaiacol with $0.1 \mathrm{ml}$ of $30 \% \mathrm{H}_{2} \mathrm{O}_{2}$ and $99.8 \mathrm{ml}$ of $0.1 \mathrm{M}$ potassium phosphate buffer. The supernatant obtained after separation $(0.12 \mathrm{ml})$ was added $3.48 \mathrm{ml}$ of POD substrate solution and the absorbance was read at $470 \mathrm{~nm}$ after a period of $20 \mathrm{~min}$ by a UV-VIS Spectrophotometer (722N, Inesa, China). A blank was performed similarly by replacing the extract with $0.12 \mathrm{~mL}$ distilled water. The POD activity was expressed as U/g and calculated using equation 1.

$$
\text { Peroxidase }(\mathrm{U} / \mathrm{g})=\frac{\Delta A \times 100}{t \times 0,12 \times m},
$$

where $\Delta A$ - absorbance difference of the tomato and blank sample, $t$ - reaction time ( $\mathrm{min}$ ), $m$ - sample weight $(\mathrm{g})$.

\section{Anthocyanin content}

The total anthocyanin content of tomatoes was determined using the spectrophotometric $\mathrm{pH}$ differential method of Lee et al. [29] with some modifications. The volume of $5 \mathrm{~g}$ tomato puree was increased to $50 \mathrm{ml}$ with a mixture of ethanol and water 
(volume ratio of $1: 1$ ) containing $1 \%$ of $\mathrm{HCl}$. The extraction was performed in a shaker at $180 \mathrm{rpm}$ for $60 \mathrm{~min}$ and then the mixture was centrifuged at $7000 \times \mathrm{g}$ for $10 \mathrm{~min}$. The supernatant was diluted with two buffers of $0.025 \mathrm{M}$ potassium chloride with $\mathrm{pH} 1.0$ and $0.4 \mathrm{M}$ sodium acetate with $\mathrm{pH} 4.5$. The absorbances of both dilutions were recorded at both 520 and $700 \mathrm{~nm}$ compared with the distilled water blank. The anthocyanin content was expressed as $\mathrm{mgCE} / 100 \mathrm{~g}$ with CE stand for cyanidin-3-glucoside equivalent and calculated by equation 2 .

Anthocyanin content $(\mathrm{mgCE} / 100 \mathrm{~g})=\frac{A \times M \times k \times V}{m \times \varepsilon \times l} \times 100 \times 1000,(2)$

where $A-\left(\mathrm{A}_{520 \mathrm{~nm}}-\mathrm{A}_{700 \mathrm{~nm}}\right) \mathrm{pH} 1.0-\left(\mathrm{A}_{520 \mathrm{~nm}}-\mathrm{A}_{700 \mathrm{~nm}}\right)$ $\mathrm{pH}$ 4.5, $M$ - molecular weight of cyanidin-3-glucoside $(449.2 \mathrm{~g} / \mathrm{mol}), k$ - dilution factor, $V-$ extract volume (ml), $m$ - sample weight (g), $\varepsilon$ - molar absorptivity coefficient of cyanidin-3-glucoside (26900 l/mol.cm), $l$ - pathlength $(1 \mathrm{~cm})$.

\section{Kinetic study}

Previous studies $[10,30,31]$ have shown that the thermal inactivation of POD and degradation of anthocyanin followed the simple first-order reaction kinetic (equation 3):

$$
\frac{C_{t}}{C_{o}}=e^{-k t}
$$

where $C_{t}$ - enzyme activity or anthocyanin content after blanching for time $t, C_{o}$ - initial corresponding value, $t$ - blanching time (s), $k$ - rate constant of the $\mathrm{POD}$ inactivation or anthocyanin degradation reaction $\left(\mathrm{s}^{-1}\right)$.

From the regression curve constructed from the exponential equation, the coefficient $k$ was determined.

The half-life time $\left(t_{1 / 2}\right)$, i.e. the blanching time needed to cause the reduction of $50 \%$ of initial POD activity or anthocyanin content, was calculated by equation 4:

$$
t_{1 / 2}=\frac{\ln (2)}{k}
$$

The dependence of the reaction rate constant on the temperature was expressed by the activation energy $\left(E_{a}\right)$ value and determined according to the Arrhenius formula (equation 5). Generally, the activation energy $\left(E_{a}\right)$ is used to represent the energy that must be provided to attain the transition state of a chemical reaction [32].

$$
k(T)=k\left(T_{r e f}\right) \exp \left[\frac{\mathrm{E}_{a}}{R}\left(\frac{1}{T_{r e f}}-\frac{1}{T}\right)\right],
$$

where $T$ - absolute temperature (K), $T_{\text {ref }}$ - absolute reference temperature (K), $k(T)$ and $k\left(T_{\text {ref }}\right)$ - rate constants at temperatures $T$ and $T_{\text {rep }}$ respectively, $E_{a}$ - energy of activation $(\mathrm{kJ} / \mathrm{mol}), R$ - universal gas constant $(8.314 \mathrm{~J} / \mathrm{mol} . \mathrm{K})$. The reference temperature was the average of the range investigated (i.e., $T_{\text {ref }}=$ $85^{\circ} \mathrm{C}$ ). Therefore, the $E_{a}$ value was estimated from the slope of the linear regression equation obtained by Arrhenius plots of versus 1/T.

\section{Data analysis and model evaluation}

Microsoft Excel software was used to calculate and draw graphs. Data analyses were carried out by the Statgraphics Centurion software (version XV, U.S.A.). The quality of the model was evaluated by the coefficient of determination $\left(R^{2}\right)$.

Ethical approval: The conducted research is not related to either human or animal use.

\section{RESULTS AND DISCUSSION}

\section{POD inactivation kinetic}

The results demonstrated that both blanching temperature and time significantly affected the POD activity $(p<0.05)$. The thermal inactivation of POD in black cherry tomatoes at temperatures of 75,80 , 85,90 , and $95^{\circ} \mathrm{C}$ was indicated in figure 1 . From the chart, it could be seen that the POD activity remarkably declined with the increase of time and temperature. However, the investigated temperature and time range was not enough to inactivate the total enzyme activity. At the highest temperature and the longest time $\left(95^{\circ} \mathrm{C}, 150 \mathrm{~s}\right)$, the POD activity remained $1.27 \%$ of the initial value. And kinetic analysis indicated that the POD inactivation followed the strong first-order model apparently with $R^{2}$ higher than 0.95 at all five temperatures (tab. 1). This was further illustrated by the plot of remaining POD activities $\left(\mathrm{P}_{\mathrm{t}} / \mathrm{P}_{\mathrm{o}}\right)$ vs. blanching time was reasonably fitted to the curves over most of the time (fig. 1).

This result had a good agreement with studies of Anthon et al. (2002) [30] and Ercan and Soysal [31]. These authors also reported an absolute first-order 
Table 1.

The parameters of the first-order model to represent the inactivation of POD and degradation of anthocyanin

\begin{tabular}{ccccc}
\hline Temperature $\left[{ }^{\circ} \mathrm{C}\right]$ & $\mathrm{k} \times 10^{3}\left[\mathrm{~s}^{-1}\right]$ & $\mathrm{t}_{1 / 2}[\mathrm{~s}]$ & $\mathrm{R}^{2}$ & $\mathrm{E}_{\mathrm{a}}[\mathrm{kJ} / \mathrm{mol}]$ \\
\hline 75 & $3.00^{*} \pm 0.19^{* *}$ & $231.67 \pm 14.70$ & $0.9701 \pm 0.0052$ & $129.96 \pm 2.57$ \\
\hline 80 & $6.80 \pm 0.41$ & $102.12 \pm 6.09$ & $0.9727 \pm 0.0075$ & \\
\hline 85 & $14.74 \pm 0.48$ & $47.06 \pm 1.52$ & $0.9809 \pm 0.0015$ \\
\hline 90 & $26.29 \pm 0.59$ & $26.37 \pm 0.59$ & $0.9697 \pm 0.0009$ & \\
\hline 95 & $31.91 \pm 0.70$ & $21.73 \pm 0.48$ & $0.9502 \pm 0.0084$ & $65.99 \pm 1.98$ \\
\hline 75 & Anthocyanin degradation & \\
\hline 80 & $0.250 \pm 0.020$ & $2784.49 \pm 223.47$ & $0.9149 \pm 0.0099$ & \\
\hline 85 & $0.420 \pm 0.010$ & $1650.97 \pm 39.32$ & $0.9558 \pm 0.0026$ & \\
\hline 90 & $0.543 \pm 0.015$ & $1276.40 \pm 35.58$ & $0.9588 \pm 0.0091$ & \\
\hline 95 & $0.850 \pm 0.030$ & $816.15 \pm 28.82$ & $0.9701 \pm 0.0064$ & \\
\hline
\end{tabular}

Notes: "Mean; ${ }^{* *} \mathrm{STD}$ - standard deviation, $\mathrm{k}$ - rate constant, $\mathrm{t}_{1 / 2}$ - half-life time, $\mathrm{R}^{2}$ - determination coefficient, $\mathrm{E}_{\mathrm{a}}-$ activation energy

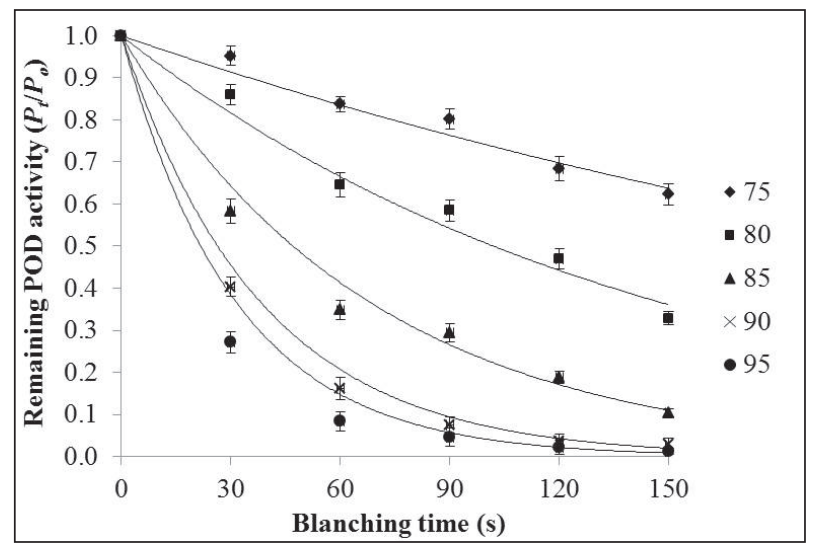

Figure 1.

Thermal inactivation of POD at temperatures of 75 to $95^{\circ} \mathrm{C}$. Notes: $P_{o}-$ initial POD activity, $P_{t}-$ POD activity after blanching, the curves represented the prediction according to the first-order kinetic model

POD thermal inactivation in both tomato crude extract and tomato juice. The first-order kinetic equation is not often obtained for the POD inactivation in most plant materials because of the presence of many POD isozymes. But tomato fruit has been proven to contain only one isozyme of POD [31] that would explain the simple kinetics we attained here. However, at the highest blanching temperatures $\left(95^{\circ} \mathrm{C}\right)$, there was a slight deviation from the curves $\left(R^{2}=0.9502\right)$. This could be accounted for the high temperature causing fruit cracking, resulting in the faster heat transfer into the fruit and the easier inactivation of the POD in the first stages.
From the predicted curves, the constants of inactivation $(k)$ were determined based on the exponential regression equation and showed in table 1 . It was observed that when the blanching temperature increased from 75 to $95^{\circ} \mathrm{C}$, the rate of POD inactivation was also raised indicated by the growth of the $k$ values from $3.00 \times 10^{-3}$ to $31.91 \times 10^{-3} \mathrm{~s}^{-1}$. The obtained $k$ values were then used to plot of lnk versus $1 / \mathrm{T}$ (Arrhenius plot) (fig. 2) indicating a sample linear fit $\left(R^{2}=0.9630\right)$.

The half-life time $\left(t_{1 / 2}\right)$ and the activation energy $\left(E_{a}\right)$ were also given in table 1 . In contrast to the parameter $k$, the $t_{1 / 2}$ values decrease with the increase of blanching temperature. The $50 \%$ reduction in the activity of POD was observed for 231.67, 102.12, $47.06,26.37$, and $21.73 \mathrm{~s}$ of blanching at $75,80,85$,

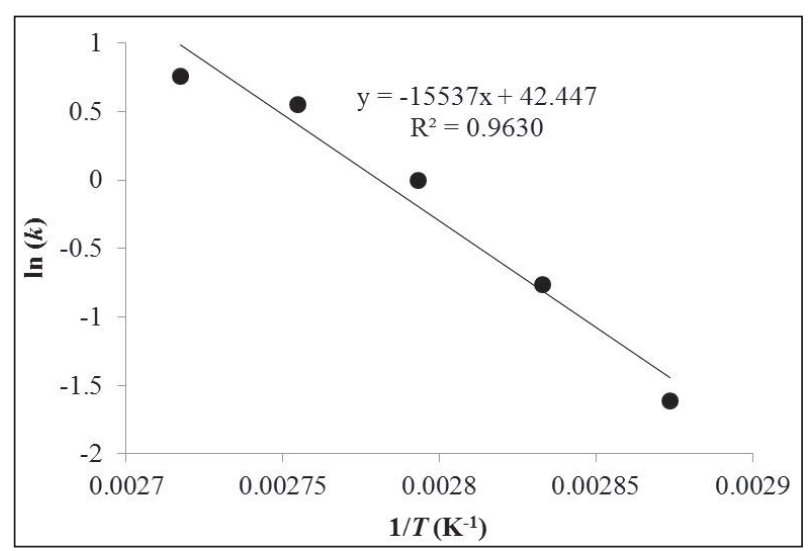

Figure 2.

Arrhenius plot of the thermal inactivation of POD

$$
\left(T_{r e f}=85^{\circ} \mathrm{C}\right)
$$


90 , and $95^{\circ} \mathrm{C}$, respectively. Meanwhile, a longer halflife time was found for POD from other sources. Deylami et al. (2016) [12] showed that a 50\% POD activity reduction in mangosteen pericarp for $547.8 \mathrm{~s}$ and $349.2 \mathrm{~s}$ of blanching at 80 and $90^{\circ} \mathrm{C}$, respectively. In another work, it was observed that the POD activity decreased $65 \%$ and $52 \%$ after heating grape peel extract and grape pulp extract at $75^{\circ} \mathrm{C}$ for $360 \mathrm{~s}$ [33]. Three principal processes have been thought to be related to the thermal POD inactivation including (1) conformational change of the protein part of an enzyme (apoenzyme); (2) removal of the pseudogroup (heme) from the haloenzyme (enzyme active site); and/or (3) degradation or modification of the pseudo-group [31].

After plotting of $\ln (k)$ by $1 / T$, the value of $E_{a}$ was simply calculated from the slope of the linear regression equation and found as $129.96 \mathrm{~kJ} / \mathrm{mol}$. Similar results were obtained for the activation energies of POD inactivation in carrot as $151.40 \mathrm{~kJ} / \mathrm{mol}$ [34], tomato crude extract as $149 \mathrm{~kJ} / \mathrm{mol}$ [30], sweet corn as 114.36 and waxy corn as $119.72 \mathrm{~kJ} / \mathrm{mol}$ [18]. However, several reports indicated higher values of $E_{a}$ for POD from other materials. For a typical example, Anthon et al. (2002) [30] found that the activation energies of POD from two tomato varieties of CXD 199 and BOS 3155 were 546 and $557 \mathrm{~kJ} / \mathrm{mol}$, respectively.

Although POD is often considered as an indicator for blanching of fruits and vegetables because of its high thermal stability, results of the half-life time and activation energy in this work showed that the POD in black cherry tomatoes (cv. OG) was less heat-stable than POD extracted from other plant sources and was readily inactivated at temperatures of $75-95^{\circ} \mathrm{C}$ but not total inactivated. The differences between study results could be due to a series of factors, including variety, maturity, pretreatment as well as an experimental methodology [31]. The pre-processing of these tomatoes by vacuum impregnation helped to increase the heat transfer capacity due to the substitution of gases by the water [35] which could contribute to the easily POD inactivation during blanching afterward. Martínez-Monzó et al. (2000) [36] proved that the impact of the gas replacement in the apple pores with the isotonic liquid led to a considerable increase of thermal conductivity (15-24\%). This was also demonstrated in our previous study, the black cherry tomatoes which not vacuum infiltrated had remaining POD activity of $29.78 \%$ and anthocyanin content of $63.69 \mathrm{mgCE} / 100 \mathrm{~g}$ DW after blanching at $90^{\circ} \mathrm{C}$ for $60 \mathrm{~s}$, meanwhile, these two responses were obtained lower values
(12.24\% and $62.70 \mathrm{mgCE} / 100 \mathrm{DW}$, respectively) in fruits infiltrated at the optimum vacuum condition (620 mmHg, $22 \mathrm{~min}$ ) before blanching [37].

\section{Anthocyanin degradation kinetic}

The results also showed the significant effect of both blanching temperature and time on the anthocyanin loss ( $p<0.05$, data not shown).

A kinetic study was carried out by plotting the residual anthocyanin content $\left(A / A_{o}\right)$ as an exponential function of exposure time for different temperatures (fig. 3). It could be observed from this graph that the degradation rate of black cherry tomatoes anthocyanin increased as the temperature increased. And the sample first-order model of anthocyanin thermal degradation obtained at five temperatures (the $R^{2}$ values in table 1 were all greater than 0.91) was similar to previous studies $[27,38]$. However, at three low blanching temperatures $\left(75,80\right.$, and $\left.85^{\circ} \mathrm{C}\right)$, the residual anthocyanin content after blanching of $30 \mathrm{~s}$ had a slightly higher deviation compared to the regression curves leading to the lower $R^{2}$ value. The reason was that when heated at low temperatures for a short time, anthocyanin not only decreased but also increased a little. This could be due to the interconversion of anthocyanin isomers [39]. In contrast, when blanched at high temperatures $\left(90\right.$ and $\left.95^{\circ} \mathrm{C}\right)$, anthocyanin lost very quickly by both the thermal degradation and dissolution in blanched water due to the cracking of the fruits.

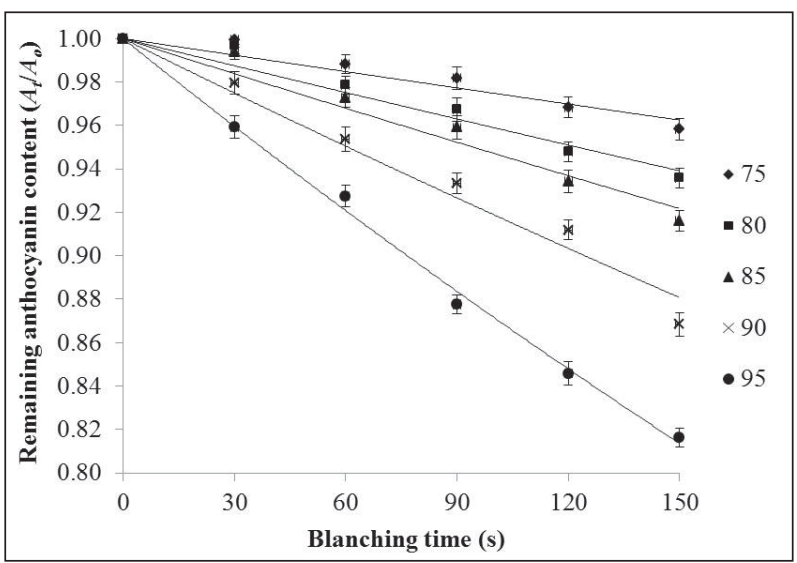

Figure 3.

The thermal degradation of anthocyanin at temperatures of $75-95^{\circ} \mathrm{C}$. (Notes: $A_{o}$ - initial anthocyanin content; $A_{t}$ - anthocyanin content after blanching; the curves represented the prediction according to the first-order kinetic model) 
The rate constants $(k)$ obtained from the firstorder equations were fitted to an Arrhenius-type plot (fig. 4) to establish the effect of temperature on the rate of anthocyanin degradation in black cherry tomatoes. And regression analysis showed that blanching temperature and $k$ values had a strong linear dependence $\left(R^{2}=0.9847\right)$.

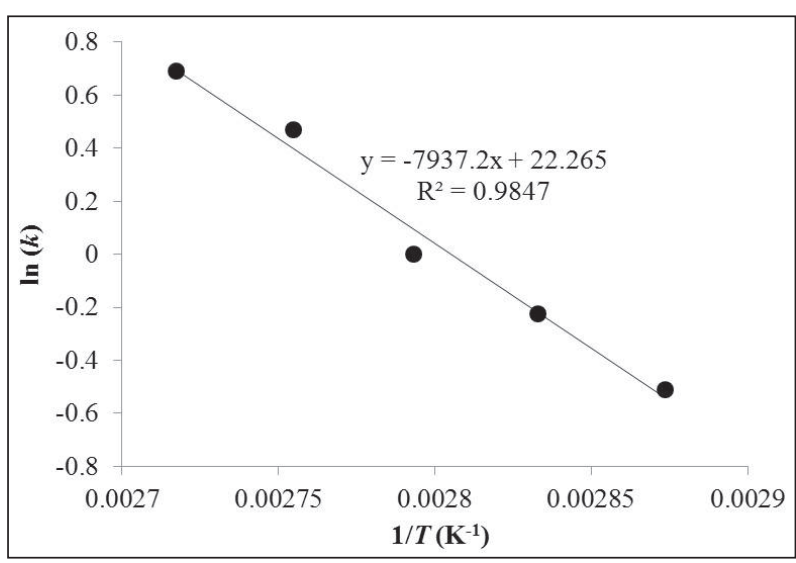

Figure 4.

Arrhenius plot of the thermal degradation of anthocya$\operatorname{nin}\left(T_{r e f}=85^{\circ} \mathrm{C}\right)$

Kinetic parameters, including degradation rate constant $(k)$ and half-life time $\left(t_{1 / 2}\right)$ for anthocyanin, were determined from the coefficient of the exponential regression equation obtained from the curves in figure 3 and presented in table 1 . As a fact, the $k$ values increased (from $0.250 \times 10^{-3}$ to $1.377 \times 10^{-3} \mathrm{~s}^{-1}$ ) with temperature (from 75 to $95^{\circ} \mathrm{C}$ ), meaning that higher blanching temperatures results in a greater and more rapid loss of anthocyanin than the use of low blanching temperatures. Temperature rise induces the loss of the glycosyl moieties of the anthocyanins by hydrolysis of the glycosidic bond. This leads to further loss of anthocyanin, since the aglycones are much less stable than their glycosidic forms. It is postulated that the formation of a chalcone is the first step in the thermal degradation of anthocyanins [40].

The calculated $t_{1 / 2}$ values were $2784.49,1650.97$, $1276.40,816.15$ and $503.61 \mathrm{~s}$ at $75,80,85,90$ and $95^{\circ} \mathrm{C}$, respectively. These $t_{1 / 2}$ values were notable lower than the results of Martynenko and Chen [32] who reported the half-life time of anthocyanin in the blueberry puree as 11238 and $4836 \mathrm{~s}$ at 80 and $95^{\circ} \mathrm{C}$. The energy of activation $\left(E_{a}\right)$ was also an important parameter to evaluate the degradation of anthocyanin. The calculated $E_{a}$ value was $65.99 \mathrm{~kJ} / \mathrm{mol}$, which is much lower than the reported value of 81-94 kJ/mol for anthocyanin degradation in blackcurrant, maqui berry and blueberry [41]. The higher
$E_{a}$ indicated that anthocyanin in black cherry tomatoes (cv. OG) was more susceptible to degradation by exposure to blanching temperatures increasing as compared to blueberry. The reason was that anthocyanin in black cherry tomatoes concentrated in the outer skin and tissue, while anthocyanin in other fruits (such as blueberry) was distributed throughout the fruit.

From the above results, it was observed that the higher the blanching temperature and the longer the blanching time is, the higher is the loss of peroxidase and anthocyanin. However, the goal of blanching was to inactivate as much $\mathrm{POD}$ as possible while retaining maximum anthocyanin content. At $90^{\circ} \mathrm{C}$, the remaining POD activity after blanching for 30 , $60,90,120$ and $150 \mathrm{~s}$ was $40.36 \%, 16.10 \%, 7.45 \%$, $3.70 \%$ and $2.83 \%$. Meanwhile, at $95^{\circ} \mathrm{C}$, the remaining POD activity was $27.15 \%, 8,38 \%, 4.64 \%, 2.18 \%$ and $1.27 \%$, respectively. Similarly, the remaining anthocyanin content was $97.96 \%, 95.37 \%, 93.33 \%$, $91.18 \%, 86.85 \%$ after blanching at $90^{\circ} \mathrm{C}$ for $30,60,90$, $120,150 \mathrm{~s}$, respectively and $95.92 \%, 92.74 \%, 87.76 \%$, $84.58 \%, 81.63 \%$ after blanching at $95^{\circ} \mathrm{C}$ for the corresponding times. Blanching at high temperatures for a long time $\left(90^{\circ} \mathrm{C}\right.$ for $120-150 \mathrm{~s}$ and $95^{\circ} \mathrm{C}$ for 90-150 s) significantly reduces the POD activity but causes cracking of the fruit, which was also a contributing factor to the reduction of POD activity by dissolving in blanched water, but in parallel, nutrients were also significant losses. Therefore, the two blanching conditions that inactivated a maximum POD and did not cause cracking were $90^{\circ} \mathrm{C}$ for $90 \mathrm{~s}$ and $95^{\circ} \mathrm{C}$ for $60 \mathrm{~s}$, inactivating $92.55 \%$ and $91.62 \%$ POD, respectively. However, blanching at $95^{\circ} \mathrm{C}$ for $60 \mathrm{~s}$ causes more anthocyanin loss than blanching at $90^{\circ} \mathrm{C}$ for $90 \mathrm{~s}$ ( $7.26 \%$ compared to $\left.6.67 \%\right)$. Therefore, suitable blanching temperature and time for black cherry tomatoes were $90^{\circ} \mathrm{C}$ for $90 \mathrm{~s}$.

\section{CONCLUSION}

The present work evaluated the effect of blanching parameters, including temperature and exposure time, on the inactivation of POD and degradation of anthocyanin in black cherry tomatoes (cv. OG). Kinetics of these two processes followed the first-order equation with activation energies of 129.96 and $65.99 \mathrm{~kJ} / \mathrm{mol}$. Results indicated that POD and anthocyanin in black cherry tomatoes in this study were more sensitive to temperature than several other fruits. It was due to the differences in structure and blanching conditions used such as blanching temperature and time, 
and also vacuum impregnation used before blanching. This mathematical modeling could be used in estimating the remaining POD activity or anthocyanin content after blanching from the temperature-time profile and kinetic parameters. Moreover, in order to inactivate the POD as much as possible while maintaining the maximum anthocyanin content in black cherry tomatoes, the best temperature and blanching time was chosen to be $90^{\circ} \mathrm{C}$ for $90 \mathrm{~s}$. Further prospective studies at a larger scale should be carried out for application in industrial production.

Conflict of interest: Authors declare no conflict of interest.

\section{REFERENCES}

1. Zhang W, Xie F, Lan X, Gong S, Wang Z. Characteristics of pectin from black cherry tomato waste modified by dynamic high-pressure microfluidization. J Food Eng 2018; 216:90-97. doi: https:// doi.org/10.1016/j.jfoodeng.2017.07.032

2. Constantino LV, Rossetto LM, Benassi MT, Oliveira C, Zeffa DM, Koltun A et al. Physico-biochemical characterization of mini-tomatoes and internal preference mapping based on consumer acceptance. Sci Hortic 2021; 282:110034. doi: https://doi.org/10.1016/j.scienta.2021.110034

3. Li H, Deng Z, Liu R, Young JC, Zhu H, Loewen S, Tsao R. Characterization of phytochemicals and antioxidant activities of a purple tomato (Solanum lycopersicum L.). J Agric Food Chem 2011; 59(21):11803-11811. doi: https://doi.org/10.1021/ jf202364v

4. Liu Y, Tikunov Y, Schouten RE, Marcelis LF, Visser RG, Bovy A. Anthocyanin biosynthesis and degradation mechanisms in Solanaceous vegetables: a review. Front Chem 2018; 6:52. doi: https:// doi.org/10.3389/fchem.2018.00052

5. Xiao HW, Bai JW, Sun DW, Gao ZJ. The application of superheated steam impingement blanching (SSIB) in agricultural products processing A review. J Food Eng 2014; 132:39-47. doi: https://doi.org/10.1016/j.jfoodeng.2014.01.032

6. Zhu Y, Pan Z, McHugh TH, Barrett DM. Processing and quality characteristics of apple slices processed under simultaneous infrared dry- blanching and dehydration with intermittent heating. J Food Eng 2010; 97(1):8-16. doi: https:// doi.org/10.1016/j.jfoodeng. 2009.07.021

7. Wang H, Zhang Q, Mujumdar AS, Fang XM, Wang J, Pei YP et al. High-humidity hot air impingement blanching (HHAIB) efficiently inactivates enzymes, enhances extraction of phytochemicals and mitigates brown actions of chili pepper. Food Control 2020; 111:107050. doi: https://doi.org/10.1016/j. foodcont.2019.107050

8. Rawson A, Patras A, Tiwari BK, Noci F, Koutchma T, Brunton N. Effect of thermal and nonthermal processing technologies on the bioactive content of exotic fruits and their products: Review of recent advances. Food Res Int 2011; 44(7):1875-1887. doi: https://doi.org/10.1016/j. foodres.2011.02.053

9. Klee HJ. Purple tomatoes: longer lasting, less disease, and better for you. Curr Biol 2013; 23(12): R520-R521. doi: https://doi.org/10.1016/j. cub.2013.05.010

10. Patras A, Brunton NP, O'Donnell C, Tiwari BK. Effect of thermal processing on anthocyanin stability in foods; mechanisms and kinetics of degradation. Trends Food Sci Technol 2010; 21(1):311. doi: https://doi.org/10.1016/j.tifs.2009.07.004

11. Van Boekel MA. Kinetic modeling of food quality: a critical review. Compr Rev Food Sci Food Saf 2008; 7(1):144-158. doi: https://doi. org/10.1111/j.1541-4337.2007.00036.x

12. Deylami MZ, Rahman RA, Tan CP, Bakar J, Olusegun L. Effect of blanching on enzyme activity, color changes, anthocyanin stability and extractability of mangosteen pericarp: A kinetic study. J Food Eng 2016; 178:12-19. doi: https:// doi.org/10.1016/j.jfoodeng.2016.01. 001

13. Gonçalves EM, Pinheiro J, Abreu M, Brandão TR, Silva CL. Modelling the kinetics of peroxidase inactivation, colour and texture changes of pumpkin (Cucurbita maxima L.) during blanching. J Food Eng 2007; 81(4):693-701. doi: https:// doi.org/10.1016/j.jfoodeng. 2007.01.011

14. Zheng $\mathrm{H}, \mathrm{Lu} \mathrm{H}$. Effect of microwave pretreatment on the kinetics of ascorbic acid degradation and peroxidase inactivation in different 
parts of green asparagus (Asparagus officinalis L.) during water blanching. Food Chem 2011; 128(4):1087-1093. doi: https://doi.org/10.1016/j. foodchem.2011.03.130

15. Ganjloo A, Rahman RA, Osman A, Bakar J, Bimakr M. Kinetics of crude peroxidase inactivation and color changes of thermally treated seedless guava (Psidium guajava L.). Food Bioproc Tech 2011; 4(8):1442-1449. doi: https://doi. org/10.1007/s11947-009-0245-4

16. Neves FI, Vieira MC, Silva CL. Inactivation kinetics of peroxidase in zucchini (Cucurbita pepo L.) by heat and UV-C radiation. Innov Food Sci Emerg Technol 2012; 13:158-162. doi: https://doi. org/10.1016/j.ifset.2011.10.013

17. Fante L, Noreña CPZ. Enzyme inactivation kinetics and colour changes in garlic (Allium sativum L.) blanched under different conditions. J Food Eng 2012; 108(3):436-443. doi: https://doi. org/10.1016/j.jfoodeng.2011.08.024

18. Liu F, Niu L, Li D, Liu C, Jin B. Kinetic characterization and thermal inactivation of peroxidase in aqueous extracts from sweet corn and waxy corn. Food Bioproc Tech 2013; 6(10):2800-2807. doi: https://doi.org/10.1007/s11947-012-0996-1

19. Deylami MZ, Rahman RA, Tan CP, Bakar J, Olusegun I. Thermodynamics and kinetics of thermal inactivation of peroxidase from mangosteen (Garcinia mangostana L.) pericarp. J Eng Sci Technol 2014; 9:374-383.

20. Gomes CF, Sarkis JR, Marczak LDF. Ohmic blanching of Tetsukabuto pumpkin: Effects on peroxidase inactivation kinetics and color changes. J Food Eng 2018; 233:74-80. doi: https://doi. org/10.1016/j.jfoodeng.2018.04.001

21. Morales-Blancas EF, Chandia VE, Cisneros-Zevallos L. Thermal inactivation kinetics of peroxidase and lipoxygenase from broccoli, green asparagus and carrots. J Food Sci 2002; 67(1):146-154. doi: https://doi.org/10.1111/j.1365-2621.2002. tb11375.x

22. Verbeyst L, Oey I, Van der Plancken I, Hendrickx M, Van Loey A. Kinetic study on the thermal and pressure degradation of anthocyanins in strawberries. Food Chem 2010; 123(2):269-274. doi: https://doi.org/10.1016/j.foodchem.2010.04.027
23. Verbeyst L, Van Crombruggen K, Van der Plancken I, Hendrickx M, Van Loey A. Anthocyanin degradation kinetics during thermal and high pressure treatments of raspberries. J Food Eng 2011; 105(3):513-521. doi: https://doi. org/10.1016/j.jfoodeng.2011. 03.015

24. Hou Z, Qin P, Zhang Y, Cui S, Ren G. Identification of anthocyanins isolated from black rice (Oryza sativa L.) and their degradation kinetics. Food Res Int 2013; 50(2):691-697. doi: https:// doi.org/10.1016/j.foodres.2011.07.037

25. Li J, Song H, Dong N, Zhao G. Degradation kinetics of anthocyanins from purple sweet potato (Ipomoea batatas L.) as affected by ascorbic acid. Food Sci Biotechnol 2014; 23(1):89-96. doi: https://doi.org/10.1007/s10068-014-0012-9

26. Garba U, Kaur S, Gurumayum S, Rasane, P. Effect of hot water blanching time and drying temperature on the thin layer drying kinetics of and anthocyanin degradation in black carrot (Daucus carota L.) shreds. Food Technol Biotechnol 2015; 53(3):324-330. doi: https://doi.org/10.17113/ $\mathrm{ftb} \cdot 53.03 \cdot 15.3830$

27. Sarkis JR, Jaeschke DP, Mercali GD, Tessaro IC, Marczak LDF. Degradation kinetics of anthocyanins in blackberry pulp during ohmic and conventional heating. Int Food Res J 2019; 26(1):8797.

28. Ha HTN, Thuy NM. Effect of thermal treatment on quality of black cherry tomatoes (Solanum lycopersicum $\mathrm{cv}$. OG): optimization of the blanching parameters. Int J Agron Agri R. 2020; 16(4):1-10.

29. Lee J, Durst RW, Wrolstad RE. Determination of total monomeric anthocyanin pigment content of fruit juices, beverages, natural colorants, and wines by the $\mathrm{pH}$ differential method: collaborative study. J AOAC Int 2005; 88(5):1269-1278. doi: https://doi.org/10. 1093/jaoac/88.5.1269

30. Anthon GE, Sekine Y, Watanabe N, Barrett DM. Thermal inactivation of pectin methylesterase, polygalacturonase, and peroxidase in tomato juice. J Agric Food Chem 2002; 50(21):61536159. doi: https://doi.org/10.1021/jf020462r

31. Ercan SŞ, Soysal Ç. Effect of ultrasound and temperature on tomato peroxidase. Ultrason 
Sonochem 2011; 18(2):689-695. doi: https://doi. org/10.1016/j.ultsonch.2010.09.014

32. Martynenko A, Chen Y. Degradation kinetics of total anthocyanins and formation of polymeric color in blueberry hydrothermodynamic (HTD) processing. J Food Eng 2016; 171:44-51. doi: https://doi.org/10.1016/j.jfoodeng.2015.10.008

33. Troiani EDP, Tropiani CT, Clemente E. Peroxidase (POD) and polyphenoloxidase (PPO) in grape (Vitis vinifera L.). Ciênc e Agrotecnologia 2003; 27(3):635-642.

34. Gonçalves EM, Pinheiro J, Abreu M, Brandão TRS, Silva CLM. Carrot (Daucus carota L.) peroxidase inactivation, phenolic content and physical changes kinetics due to blanching. J Food Eng 2010; 97(4):574-581. doi: https://doi. org/10.1016/j.jfoodeng.2009.12.005

35. Zhao Y, Xie J. Practical applications of vacuum impregnation in fruit and vegetable processing. Trends Food Sci Technol 2004; 15(9):434-451. doi: https://doi.org/10.1016/j.tifs. 2004.01.008

36. Martínez-Monzó J, Barat JM, González-Martínez C, Chiralt A, Fito P. Changes in thermal properties of apple due to vacuum impregnation. J Food Eng 2000; 43(4):213-218. doi: https://doi. org/10.1016/S0260-8774(99)00152-1

37. Ha HTN, Thuy NM. Optimization of vacuum infiltration before blanching of black cherry tomatoes (Solanum lycopersicum cv. OG) using response surface methodology. Food Res 2020; 4(4):1317-1325. doi: https://doi.org/10.26656/ fr.2017.4(4).100
38. Kechinski CP, Guimarães PVR, Noreña CPZ, Tessaro IC, Marczak LDF. Degradation kinetics of anthocyanin in blueberry juice during thermal treatment. J Food Sci. 2010; 75(2): C173-C176. doi: https://doi.org/10.1111/j.17503841.2009.01479.x

39. Scalzo RL, Genna A, Branca F, Chedin M, Chassaigne $\mathrm{H}$. Anthocyanin composition of cauliflower (Brassica oleracea L. var. botrytis) and cabbage (B. oleracea L. var. capitata) and its stability in relation to thermal treatments. Food Chem 2008; 107(1):136-144. doi: https://doi.org/10.1016/j. foodchem.2007.07.072

40. Ibarhium AMA. Determination of anthocyanins content in crude and processed roselle (Hibiscus sabdriffa) calyces, and strawberries (Fragaria ananassa) fruit. Doctoral dissertation, University of Gezira. 2012.

41. Busso Casati C, Baeza R, Sánchez V. Comparison of the kinetics of monomeric anthocyanins loss and colour changes in thermally treated blackcurrant, maqui berry and blueberry pulps from Argentina. J Berry Res 2017; 7(2):85-96. 